\title{
Unilatus unilatus Mizelle \& Kritsky, 1967 (Monogenea, Ancyrocephalinae) in Hypostomus spp. (Siluriformes, Loricariidae) from the Chavantes reservoir, São Paulo State, Brazil
}

\author{
É. O. P. ZICA ${ }^{1,3}$, V. D. ABDALLAH ${ }^{1,4}$, R. K. DE AZEVEDO ${ }^{1,4}$, A. C. WUNDERLICH ${ }^{1,3}$, E. D. CARVALHO ${ }^{2,5}$, \\ R. J. SILVA ${ }^{1,5}$
}

${ }^{1}$ UNESP - Univ Estadual Paulista, Campus de Botucatu, Instituto de Biociências, Departamento de Parasitologia, Botucatu, São Paulo, Brazil. Distrito Rubião Júnior, s/n., Cep: 18618-970, Botucatu, SP, Brazil,

E-mail: ericazica@hotmail.com; ${ }^{2}$ UNESP - Univ Estadual Paulista, Campus de Botucatu, Instituto de Biociências, Departamento de Morfologia, Botucatu, São Paulo, Brazil; ${ }^{3}$ Bolsista doutorado CNPq (Conselho Nacional de Pesquisa

e Desenvolvimento Científico); ${ }^{4}$ Bolsista pós-doutorado FAPESP (Fundação de Amparo a Pesquisa do Estado de São Paulo); ${ }^{5}$ Pesquisador do CNPq (Conselho Nacional de Pesquisa e Desenvolvimento Científico)

\begin{abstract}
Summary
In this paper, the occurrence and new morphological data of Unilatus unilatus Mizelle et Kritsky, 1967 from the gills of Hypostomus strigaticeps (Regan, 1907), Hypostomus regani (Ihering, 1905), and Hypostomus iheringii (Regan, 1908) from the Chavantes reservoir, São Paulo State, Brazil are reported. Unilatus unilatus from this reservoir presents differences in relation to the holotype previously described such as, eggs with no bifid or trifid filament and a rounded termination, anterior bar slightly curved with a posterior projection, and posterior bar which may present three shapes. This is the first record of $U$. unilatus in southeastern Brazil outside the Amazon River Basin, with $H$. strigaticeps, H. regani and H. iheringii as new hosts.
\end{abstract}

Keywords: Ancyrocephalinae; Unilatus unilatus; ectoparasite; Loricaridae; Hypostomus; Chavantes reservoir

\section{Introduction}

Unilatus unilatus Mizelle \& Kritsky, 1967 was initially described in Plecostomus sp. (= Hypostomus sp.) obtained from the Steinhart Aquarium, California Academy of Sciences, San Francisco (collected in Amazon River Basin, Brazil) (Mizelle \& Kritsky, 1967). Posteriorly, Mizelle et al. (1968) proposed a redescription for this species with more detailed drawings and Molnar et al. (1974) reported this species in Hypostomus robinii Valenciennes, 1840, Talparo River near Talparo, Trinidad and Tobago. Currently, the genus Unilatus includes seven species: Unilatus anoculus (Price, 1968) from Plecostomus bolivianus Pearson, 1924; U. brevispinus Suriano, 1985 from Pterygoplichthys multiradiatus (Hancock, 1828); U. brittani Mizelle, Kritsky et Crane, 1968 from Hypostomus sp. and Plecostomus sp.; $U$. dissimilis Suriano, 1985 from Hemiancistris sp.; $U$. longispinus Suriano, 1985 from Pterygoplichthys multiradiatus; U. scaphirhynchae Suriano, 1985 from Hemiancistrus scaphirhynchae Kner, 1854; and U. unilatus Mizelle et Kritsky, 1967 from Hypostomus robinii Valenciennes, 1840, and Plecostomus sp. (Type species) (Boeger \& Vianna 2006).

During a parasitological survey in $H$. iheringii (Regan, 1908), H. regani (Ihering, 1905), and $H$. strigaticeps (Regan, 1907), specimens of $U$. unilatus were collected from the gill filaments. The shape of the anterior and posterior bars, anterior and posterior anchors, vagina, accessory piece and egg filament termination found in these fishes were slightly different in relation to the type species (Mizelle \& Kritski, 1967; Mizelle et al., 1968).

In this paper, we provide new information on the geographical location, new hosts, and complementary morphological data on $U$. unilatus on the basis of specimens collected in Hypostomus spp. from the upper Paraná basin.

\section{Materials and methods}

Five specimens of Hypostomus strigaticeps measuring $12.94 \mathrm{~cm}(9.2-16.3 \mathrm{~cm})$, one specimen of $H$. regani $(14.7$ $\mathrm{cm})$, and another one of $H$. iheringii $(16.2 \mathrm{~cm})$ were collected with nets in October and November 2010 in the upper Paraná basin, municipality of Ipaussu, São Paulo State, Brazil. The Chavantes reservoir is located in the middle of the Paranapanema River, between the São Paulo and Paraná States (Zica et al., 2009).

The gills were removed from the hosts and placed in vials containing hot water (about $70-75^{\circ} \mathrm{C}$ ). Posteriorly, they were shaken and absolute ethanol was added, and the monogeneans were collected using a stereomicroscope (Boeger \& Vianna, 2006). Some specimens were stained 
with Gomori's trichrome and mounted in Canada balsam for analysis of internal organs (Eiras et al., 2006). Other specimens were mounted in Gray and Wess' medium (Humason, 1979) to study of sclerotized structures. Measurements are given in micrometers and are presented as mean followed by range in parentheses. The illustrations of the sclerotized structures were made with the aid of a camera lucida mounted on a Leica DMLS microscope, while the photographs were made using a differential interference contrast microscope (Leica DM 5000B). Voucher host fish specimens were deposited in the fish collection of the Laboratório de Biologia e Genética de
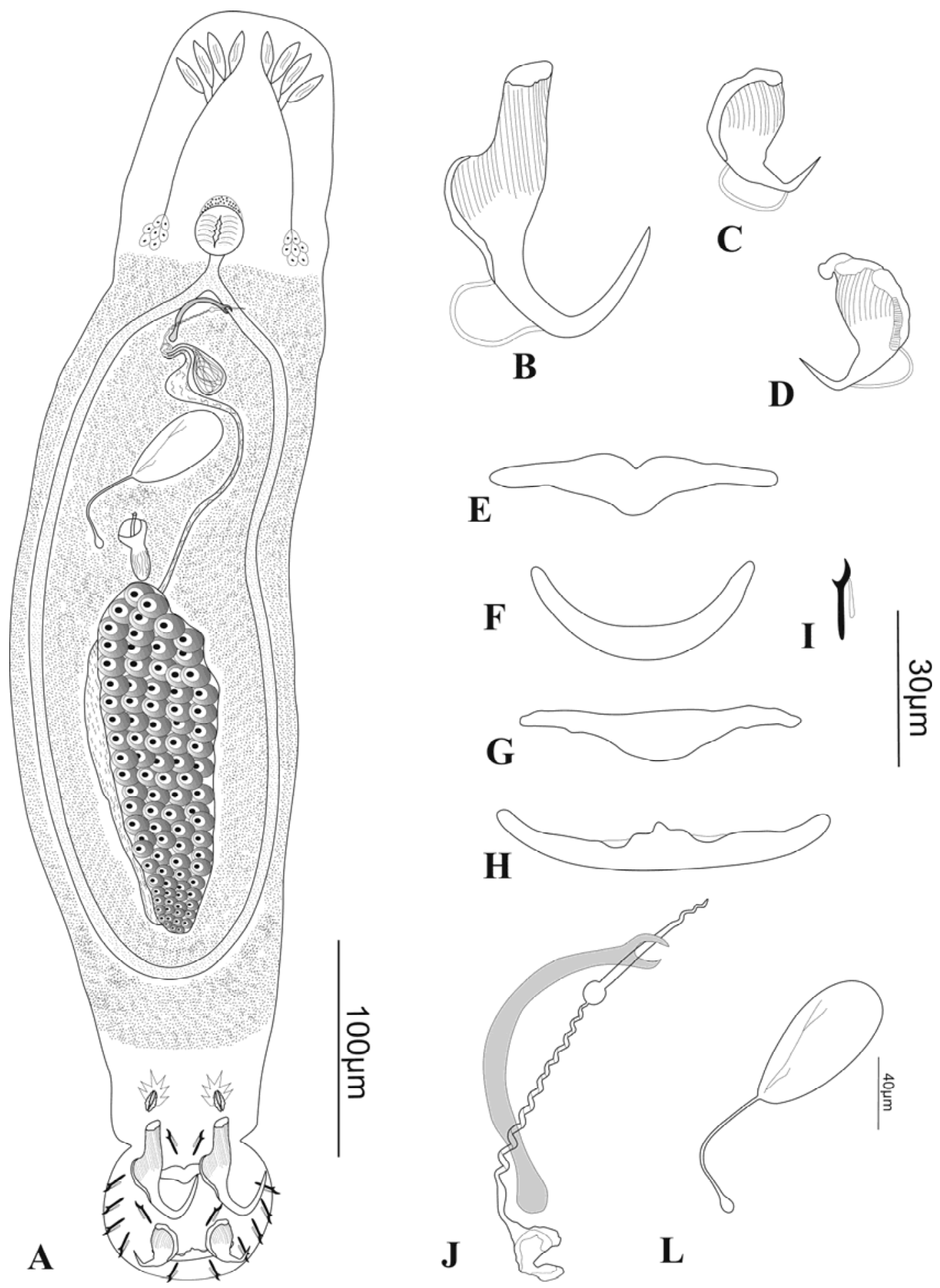

Fig. 1. Unilatus unilatus Mizelle \& Kritsky, 1967 (A) Whole worm, ventral view. (B) Anterior anchor. (C, D) Posterior anchor. (E) Anterior bar. (F, G, H) Posterior bar. (I) Hook. (J) Male copulatory complex: MCO and accessory piece. (L) Egg. All figures are to the same scale $(30 \mu \mathrm{m})$ except figure $\mathrm{A}(100 \mu \mathrm{m})$ and figure $\mathrm{L}(40 \mu \mathrm{m})$. 
Peixes (LBP), Universidade Estadual Paulista (UNESP), municipality of Botucatu, São Paulo State, Brazil. Voucher helminth specimens were deposited in the Helminthological Collection of the Departamento de Parasitologia of the Instituto de Biociências (CHIBB), UNESP, municipality of Botucatu, São Paulo State.

\section{Results}

Dactylogyridae Bychowski, 1933

Ancyrocephalinae Bychowski, 1937

Unilatus unilatus Mizelle \& Kritsky, 1967

Hosts: Hypostomus iheringii (LBP 12232), H. regani (LBP 12233), and H. strigaticeps (LBP 12234) (Siluriformes, Loricariidae).

Locality: Chavantes reservoir, municipality of Ipaussu, São Paulo, Brazil (23 ${ }^{\circ} 07^{\prime} 36^{\prime \prime} \mathrm{S}$ and $\left.49^{\circ} 37^{\prime} 35^{\prime \prime} \mathrm{W}\right)$.

Site of infection: Gills

Specimens deposited: Vouchers, CHIBB 050L, 051L, 052L. Prevalence: $100 \%$ (5/5 in Hypostomus strigaticeps, $1 / 1$ in $H$. regani and $1 / 1$ in $H$. iheringii).

Mean intensity: 2.14 in Hypostomus strigaticeps, 4 in $H$. regani and 3 in $H$. iheringii.

Specimens studied: 10 in Gray and Wess' medium and 2 stained with Gomori's trichrome.

Morphological description (morphometric measurements are presented on Table 1)

Based on 12 specimens: Body fusiform, 579 (475 - 680) long; greatest width $138(96$ - 176) near mid-length (Figs. 1A; 2A). Cephalic lobes incipient or absent. Three head organs extensive; cephalic glands inconspicuous, posterolateral to pharynx. Pharynx subspherical, anterior part smaller; 23 (21 - 25) long, $20.5(19-21)$ wide. Pair of accessory structures at junction of peduncle, ornamented and striated (Fig. 1A). Haptor subovate, 69 (59-75) long, 84 (71 - 93) wide. Anterior anchor superficial root elongate with slight slots; anchor $54(50-55)$ long, base 18 (14 -20 ) wide (Figs. 1B; 2B). Posterior anchor may present as one of two shapes with heavily sclerotized basal border, point bent a maximum of $90^{\circ}$ (Fig. 1C), anchor 24 (2325) long, base 15 (12 - 17) width (Figs. 1C, D). Anterior bar slightly curved with rounded ends and posterior projection, 52 (49 - 56) long (Fig. 1E). Posterior bar may present as one of three shapes: bowed (Fig. 1F); straight with rounded ends directed posteriorly and with posterior projection (Fig. 1G); or straight with rounded ends directed anteriorly, anterior projection and two slight depressions (Fig. 1H), 56 (49 - 59) long. Hook $14(11-16)$ long, with slightly curved shaft, straight shank (Fig. 1I). Loop 0.7 shank long. Gonads ovate, ovary elongate and larger, 130 (111 - 149) long, $43(20$ - 50) wide; testis subovate 112 (90 - 121) long, 29 (15 - 41) wide. Cirrus elongate, proximal and distal parts of shaft spiraled with knob and cirral thread between, cirrus $81(76-89)$ long. Accessory piece curved, distally bifid, 63 (59 - 68) long (Figs. 1J; 2C). Seminal vesicle elongate; prostatic reservoir saccate. Vagina ventral well sclerotized, funnel-shaped; seminal receptacle not observed. Vitelline follicles densely distributed in trunk; egg elongate-ovate with filament proximally rounded (Figs. 1L; 2D), 72 (42 - 88) long, 41 (3943) wide.

Table 1. Comparative measurements of Unilatus unilatus Mizelle \& Kritsky, 1967 from Hypostomus spp., for specimens collected in this study and published data

(measurements in micrometers; mean followed by range in parentheses; -, indicates no measurement available)

\begin{tabular}{lcc}
\hline Measurements & $\begin{array}{c}\text { Mizelle \& } \\
\text { Kritsky (1967) } \\
(\mathbf{n}=\mathbf{1 4})\end{array}$ & $\begin{array}{c}\text { Present study } \\
(\mathbf{n}=\mathbf{1 2})\end{array}$ \\
\hline Body length & 666 & 579 \\
& $(630-774)$ & $(475-680)$ \\
Body width & $131(121-145)$ & $138(96-176)$ \\
Pharynx length & - & $23(21-25)$ \\
Pharynx width & $27(24-28)$ & $20.5(19-21)$ \\
Haptor length & $87(78-90)$ & $69(59-75)$ \\
Haptor width & $86(78-90)$ & $84(71-93)$ \\
Anterior anchor length & $34(32-37)$ & $54(50-55)$ \\
Anterior anchor base width & $19(18-20)$ & $18(14-20)$ \\
Posterior anchor length & $20(19-22)$ & $24(23-25)$ \\
Posterior anchor base width & $18(17-19)$ & $15(12-17)$ \\
Anterior bar length & $27(25-28)$ & $52(49-56)$ \\
Posterior bar length & $41(38-44)$ & $56(49-59)$ \\
Hook length & $12(11-13)$ & $14(11-16)$ \\
Ovary length & - & $130(111-149)$ \\
Ovary width & - & $43(20-50)$ \\
Testes length & - & $112(90-121)$ \\
Testes width & $59(56-61)$ & $81(76-89)$ \\
Cirrus length & $63(38-48)$ & $63(59-68)$ \\
Acessory piece length & - & $72(42-88)$ \\
Egg length & $-49-43)$ \\
\hline Egg width & $-15-41)$ \\
\hline
\end{tabular}

\section{Discussion}

Our results showed new host and new geographical location for $U$. unilatus and also that the specimens found in Hypostomus spp. from the upper Paraná basin are slightly different in comparison with the specimens collected in the Amazon River basin by Mizelle and Kritsky (1967), and Mizelle et al. (1968). Mizelle and Kritsky (1967) reported in $U$. unilatus an accessory piece bifid which is straight and proximally bowed as a hook, whereas in our specimens the accessory piece is well bowed and proximally rounded. Mizelle and Kritsky (1967) also described the egg with a single bifid or trifid filament and bowed anterior and posterior bars; however, in our specimens, the egg does not have a bifid or trifid filament, the termination is rounded, the anterior bar is slightly curved with a posterior 

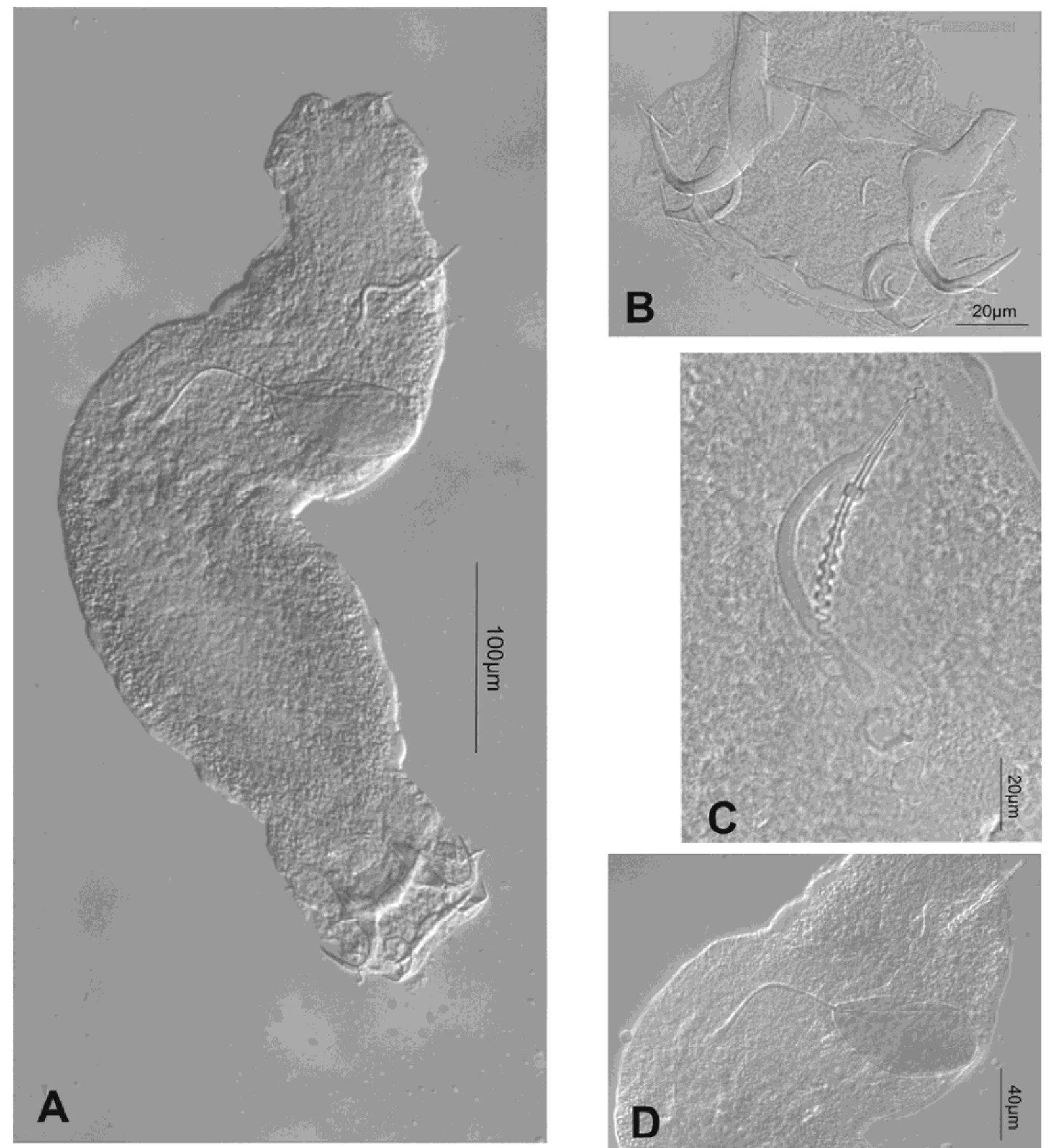

Fig. 2. Unilatus unilatus Mizelle \& Kritsky, 1967 (A) Whole worm, ventral view. (B) Anterior and posterior anchor; anterior and posterior bar (C) Copulatory complex. (D) Egg

projection, and the posterior bar may present in one of three shapes. Our specimens show an anterior anchor with slight slots and without a dual wing, while that Mizelle and Kritsky (1967) observed the anterior anchor with a dual wing, posterior proximally single and otherwise dual. These differences also may be due to orientation of bars between our specimens and of the original description. Moreover, the vagina described by Mizelle and Kritsky (1967) was associated with an expanded tube, but in specimens collected in the present study the vagina is fun- nel-shaped (see Fig 1A). Furthermore, the whole body in ventral view is lacking in illustrations of Mizelle and Kritsky (1967) but is clearly presented in our study.

Finally, the measurements of the specimens collected in hosts from the Chavantes reservoir present large differences in relation to the specimens described by Mizelle and Kritsky (1967) (Table I). This may be related to intra-species variations that are common in Monogenea or to an adaptive process (Kritsky et al., 1995). These same authors studied the morphometric variability of specimens of 
Scleroductus reported from the external surface of four Siluriformes from the Guandu river and questioned whether the observed variations in morphology and size are of specific value or result from influences of host and/or environmental factors. Justine and Grugeaud (2010) found that the sclerotized structures varied linearly with the size and age in a monocotylid. The haptor of an immature specimen provides valid characters for the description of a species. Moreover, temperature can affect the development and growth of certain species of capsalid monogeneans, especially regarding the lengths of the hamulus (Lackenby et al., 2007). Thus, the difference found between specimens of $U$. unilatus from Amazon river and upper Parana river may be explained by geographic distribution, environmental condition differences and also because our specimens were collected in another Hypostomus species. This is the first record of $U$. unilatus in southeastern Brazil, outside the Amazon River Basin, with $H$. strigaticeps, $H$. regani, and $H$. iheringii as new hosts, and also with presentation of complementary data to the morphology of this monogenoid species.

\section{Acknowledgments}

The authors would like to thank Dr. Claudio Henrique Zawadzki from the Departamento de Biologia, Centro de Ciências Biológicas, Universidade Estadual de Maringá, Paraná State, Brazil, who identified the host species in this study. We are also grateful to Kristin Nicole Taylor, from Weill Cornell Medical College, New York, USA, for the English review of the manuscript.

\section{References}

BoEger, W. A. ViannA. R. T. (2006): Monogenoidea. In: Thatcher, V. E. (Eds) Amazon Fish Parasites. Sofia, Moscow: Pensoft Publishers, pp. $42-116$
Eiras, J. C., TAKemoto, R. M., PAvanelli, G. C. (2006): Métodos de estudo e técnicas laboratoriais em parasitologia de peixes, Eduem, Maringá, 199 pp.

Humason, G. L. (1979): Animal Tissue Techniques. $4^{\text {th }}$ Edition, San Francisco, USA, W.H. Freeman Company, $661 \mathrm{pp}$.

Justine, J. L., GRUGEAUD, A. (2010): Does the number of sclerotised structures used for the systematics of monogeneans change with age? A study of the monocotylid Dendromonocotyle pipinna. Parasitol. Res., 107(6): 1509 1514. DOI: $10.1007 / \mathrm{s} 00436-010-2019-3$

Kritsky, D. C., Boeger, W. A., Popazoglo, F. (1995): Neotropical Monogenoidea. 22. Variation in Scleroductus species (Gyrodactylidae) from Siluriform fishes of Southeastern Brazil. J. Helminthol. Soc. Washington, 62: 53 - 56 LACKENBY, J. A, ChAMBERS, C. B, ERnst, I., WhitTington, I. D. (2007): Effect of water temperature on reproductive development of Benedenia seriolae (Monogenea: Capsalidae) from Seriola lalandi in Australia. Dis. Aquat. Organ., 74: 235 - 242. DOI: 10.3354/dao074235

Mizelle, J. D., KRitsKy, D. C. (1967): Unilatus gen. n. a unique neotropical Genus of Monogenea. J. Parasitol., 53(5): $1113-1114$

Mizelle, J. D., Kritsky, D. C., Crane, J. W. (1968): Studies on Monogenetic Trematodes. XXXVIII. Ancyrocephalinae from South America with the proposal of Jainus gen. n. Am. Midl. Nat., 80(1): $186-198$

Molnar, K., HaneK, G., Fernando, C. H. (1974): Ancyrocephalids (Monogenea) from freshwater fishes of Trinidad. J. Parasitol., 60(6): 914 - 920.

Zica, E. O. P., SAntos, K. R., Ramos, I. P., Zanatta, A. S., CARvalho, E. D., Silva, R.J. (2009): First case of an infection of the metacercariae of Austrodiplostomum compactum (Lutz, 1928) (Digenea, Diplostomidae) in $\mathrm{Hy}$ postomus regani (Ihering, 1905) (Siluriformes: Loricariidae). Pan-Am. J. Aquat. Sci., 4: 35 - 38 